\title{
Liver lipid content and inflammometabolic indices in peripartal dairy cows are altered in response to prepartal energy intake and postpartal intramammary inflammatory challenge ${ }^{1}$
}

\author{
D. E. Graugnard, ${ }^{*} \dagger$ K. M. Moyes,‡ E. Trevisi,§ M. J. Khan, ${ }^{\star} †$ D. Keisler,\# J. K. Drackley,†॥ G. Bertoni,§ \\ and J. J. Loor* ${ }^{2}$ \\ *Mammalian NutriPhysioGenomics, and \\ †Department of Animal Sciences, University of Illinois, Urbana 61801 \\ ‡Department of Animal and Avian Sciences, University of Maryland, College Park 20742 \\ §Istituto di Zootecnica, Facoltà di Agrarià, Università Cattolica del Sacro Cuore, 29122 Piacenza, Italy \\ \#Department of Animal Science, University of Missouri, Columbia 65211 \\ IIDivision of Nutritional Sciences, University of Illinois, Urbana 61801
}

\section{ABSTRACT}

This study evaluated the effect of feeding a control diet $(\mathrm{CON})$ or a moderate energy diet (overfed, OVE) during the dry period $(\sim 45 \mathrm{~d})$ and a postpartum intramammary lipopolysaccharide (LPS) challenge on blood metabolic and inflammatory indices, milk production, and hepatic gene expression. A subset of cows $(\mathrm{n}=9$ / diet) in CON (1.34 Mcal/kg of dry matter) and OVE (1.62 Mcal $/ \mathrm{kg}$ of dry matter) received an intramammary LPS challenge $(200 \mu \mathrm{g}$; CON-LPS, OVE-LPS, respectively). Liver biopsies were harvested at $-14 \mathrm{~d}$ from calving, and postpartum at $2.5 \mathrm{~h}$ post-LPS on d 7, 14, and 30. Prepartum, the OVE group was in more positive energy balance (EB) and had greater body condition score compared with CON. In contrast, during wk 1 postpartum and before the LPS challenge, the OVE group was in greater negative EB than CON. Prepartal diet did not affect postpartal milk production or dry matter intake. At $2 \mathrm{~h}$ postchallenge on $\mathrm{d} 7$, we observed an increase in serum nonesterified fatty acids (NEFA) and bilirubin and a decrease in hydroxybutyrate, regardless of diet. That was coupled with greater haptoglobin in OVE-LPS compared with CON-LPS. In addition, OVE-LPS cows versus CON nonchallenged, OVE nonchallenged, and CON-LPS had greater liver triacylglycerol (TAG) concentration $2.5 \mathrm{~h}$ postchallenge on $\mathrm{d}$ 7. The concentration of TAG in liver of OVE-LPS remained elevated by $30 \mathrm{~d}$ postpartum. The liver TAG concentration in OVE-LPS compared with CON-LPS cows was associated with greater serum concentration of NEFA and reactive oxygen metabolites on d 10 and 14 postpartum. Cows in OVE-LPS also had greater

Received May 1, 2012

Accepted October 30, 2012

${ }^{1}$ Supported by NRI competitive grant 2007-35204-17758.

${ }^{2}$ Corresponding author: jloor@illinois.edu concentrations of ceruloplasmin, cholesterol, and vitamin E from d 10 through 21. Among 28 genes associated with fatty acid oxidation, inflammation, oxidative stress, and gluconeogenesis, only $S A A 3$ (which encodes an acute phase protein) was greater in CON-LPS compared with OVE-LPS at $2.5 \mathrm{~h}$ postchallenge. Expression of $H P$, which encodes another acute phase protein, was greater in OVE-LPS than in CON-LPS at 14 and 30 d postpartum. Several inflammation-related genes (TNF, IRAK1, NFKB1, ANGPTL4) showed markedly decreased expression between 7 and $14 \mathrm{~d}$, after which expression remained unchanged. No differences were observed in several genes of the growth-hormone/ insulin-like growth factor-1 axis, except for SOCS2, expression of which decreased markedly between 7 and $14 \mathrm{~d}$ in OVE-LPS but not in CON-LPS. These data suggest that overfeeding a moderate-energy diet prepartum alters the response of the cow to an intramammary challenge after calving and may predispose it to sustained liver lipidosis.

Key words: inflammation, fatty liver, immunometabolism

\section{INTRODUCTION}

The negative energy balance (NEB) experienced by cows soon after calving has been associated with impaired neutrophil trafficking, phagocytosis, and killing capacity (Goff, 2006; Sordillo et al., 2009). The NEB associated with parturition leads to extensive mobilization of fatty acids stored in adipose tissue, causing marked elevations in blood NEFA and BHBA concentrations. The prepartal level of dietary energy could affect adipose tissue deposition and the amount of NEFA released into blood and available for metabolism in liver (Drackley et al., 2005). Elevated blood NEFA and BHBA, as well as dysregulated innate immunity during peripartal NEB, contribute to immunosuppres- 
sion (Burvenich et al., 2003). Moreover, cows with or without clinical symptoms of diseases experience an inflammatory status around calving, as previously shown by Bionaz et al. (2007) and Bertoni et al. (2008). The severity of inflammation around parturition seems related to some inflammatory indices observed in the dry period (Trevisi et al., 2010). Prepartal feeding of higher energy diets can lead to elevated intakes of energy and have largely failed to overcome peripartal health problems or declining fertility (Beever, 2006). Uncontrolled intake of diets with moderate energy density can increase fat deposition in visceral adipose depots (Nikkhah et al., 2008) and upon parturition leads to compromised liver metabolism (Drackley et al., 2005; Beever, 2006).

Our general hypothesis was that markers of oxidative stress, inflammation, and metabolism in blood and liver tissue after an intramammary Escherichia coli LPS challenge postpartum differ in prepartal control cows compared with energy-overfed cows. To address the hypothesis, we measured blood (plasma and serum) concentrations of reactive oxygen metabolites (ROM), vitamin $\mathrm{A}$, vitamin $\mathrm{E}, \beta$-carotene, NEFA, BHBA, bilirubin, glutamic oxalacetic transaminase (GOT), haptoglobin, ceruloplasmin, albumin, cholesterol, glucose, insulin, creatinine, triacylglycerol (TAG), and urea. Some of these molecules (e.g., haptoglobin, ceruloplasmin, albumin) are synthesized in liver and respond to inflammatory stimuli (Bertoni et al., 2008); thus, along with enzymes (GOT) and metabolites (cholesterol), they serve as indices of inflammation status, antiinflammatory status (e.g., vitamins), and liver functionality (Sordillo and Aitken, 2009). In addition to the blood parameters, the concentrations of total lipid and TAG were measured in liver tissue, along with mRNA expression of 28 genes associated with metabolism, inflammation, and stress.

\section{MATERIALS AND METHODS}

\section{Animals, Diets, and Energy Balance Calculations}

All procedures were conducted under protocols approved by the University of Illinois Institutional Animal Care and Use Committee. Details of the experimental design have been published previously (Graugnard et al., 2012). Briefly, 40 Holstein cows entering their second or greater lactation were enrolled in the study, which included animals not receiving the LPS challenge (Graugnard et al., 2012).

As described in Graugnard et al. (2012), all cows used were assigned randomly ( $\mathrm{n}=20$ per diet) to a control diet (CON, controlled energy, high fiber; $1.34 \mathrm{Mcal} /$ $\mathrm{kg}$ of diet $\mathrm{DM}$ ), which was fed ad libitum to provide approximately $100 \%$ of calculated $\mathrm{NE}_{\mathrm{L}}$ requirements, or were fed a diet to provide at least $150 \%$ of calculated $\mathrm{NE}_{\mathrm{L}}$ requirements $(\mathrm{OVE}$, overfed group; $1.62 \mathrm{Mcal} / \mathrm{kg}$ of DM] during the entire 45-d dry period (NRC, 2001; Graugnard et al., 2012). After parturition, cows were moved to a tie-stall barn, fed a common lactation diet $\left(\mathrm{NE}_{\mathrm{L}}=1.69 \mathrm{Mcal} / \mathrm{kg}\right.$ of $\left.\mathrm{DM}\right)$, and milked twice daily (0400 and $1600 \mathrm{~h}$ ).

Diets were fed as TMR once daily (0600 h) using an individual gate feeding system (American Calan, Northwood, NH) during the dry period or in open individual mangers during lactation. Calculation of energy balance, sampling of feed ingredients and TMR for composition analyses, and housing of cows pre- and postpartum were as reported previously (Graugnard et al., 2012). Details on BW, BCS, milk weights, and sampling for milk composition were as described previously (Graugnard et al., 2012).

\section{LPS Challenge}

The average composite SCC of the 40 cows was approximately $128,000 \pm 108,000$ cells $/ \mathrm{mL}$ during the previous lactation. At approximately 7 DIM, $200 \mu \mathrm{g}$ of E. coli LPS (strain 0111:B4, cat. no. L2630, Sigma Aldrich, St. Louis, MO) was infused into a rear quarter of the mammary gland of 10 cows in CON (CON-LPS) and 10 cows in OVE (OVE-LPS). Before LPS challenge $(\sim 2 \mathrm{~d})$, foremilk samples from all quarters of each cow were cultured and confirmed to be bacteriologically negative (Moyes et al., 2009). The LPS was dissolved in $20 \mathrm{~mL}$ of $0.09 \%$ sterile physiological saline (Hospira, Lake Forest, IL). Immediately after milking (0530 h), one rear mammary quarter was disinfected by using cotton wool presoaked in $70 \%$ ethanol, and the LPS was infused via a sterile disposable syringe fitted with a sterile teat cannula using the full insertion infusion method. The quarter was thoroughly massaged.

\section{Liver Biopsy and Chemical Composition}

Liver from CON-LPS and OVE-LPS as well as nonchallenged CON (CON-NC) and OVE (OVE-NC) cows (Graugnard et al., 2012) was sampled via puncture biopsy (Dann et al., 2006) under local anesthesia at approximately $0800 \mathrm{~h}$ on $\mathrm{d}-14,7$ (2.5 h post-LPS), 14 , and 30 relative to parturition. Liver was frozen immediately in liquid $\mathrm{N}$ and later analyzed for contents of total lipids and TAG and used for RNA extraction. Lipids and TAG were analyzed following protocols described before (Dann et al., 2006).

\section{Blood Metabolites and Hormones}

Details of methodologies can be found in the supplementary materials (available online at http://www. 
journalofdairyscience.org/). Briefly, blood from CONLPS and OVE-LPS was sampled from the coccygeal vein or artery at $1200 \mathrm{~h}$ on d $0,2,10,14$, and 21 relative to parturition. During d 7 (LPS challenge day), the blood samples from the cows assigned to the LPS challenge groups were collected before the LPS challenge (at $0530=0 \mathrm{~h}$ ) and at 2, 6, and $12 \mathrm{~h}$ after LPS administration. Three different samples were collected into evacuated tubes (Becton Dickinson Vacutainer Systems, Franklin Lakes, NJ) containing a clot activatoror lithium heparin for serum and plasma isolations. Measurements of NEFA, BHBA, glucose, albumin, insulin, $\beta$-carotene, cholesterol, bilirubin, creatinine, urea, GOT, haptoglobin, ceruloplasmin, vitamin A, vitamin E, total ROM, growth hormone $(\mathbf{G H})$, IGF1, and TAG were performed as described in the supplementary materials.

\section{RNA Extraction, Quantitative PCR, and Design and Evaluation of Primers}

We extracted RNA from CON-NC and OVE-NC as well as CON-LPS and OVE-LPS from liver tissue using established protocols in our laboratories (see supplementary materials or details: http://www.journalof dairyscience.org/). Details of quantitative PCR, design, and primer evaluation are presented in the supplementary materials.

\section{Statistical Analysis}

One cow in CON-LPS and one in OVE-LPS tested positive in the culture before LPS challenge and were taken out of the experiment. Thus, 9 cows in each group were used for the analysis of production and blood indices (reported in Figures 1, 2, 4, and 6). A complete set of liver biopsy samples was available for only 6 cows per treatment, which were used for analysis of liver lipid, TAG, and gene expression reported in Table 1 and Figure 3, and in Figures 7, 8, and 9. The MIXED procedure of SAS (SAS Institute Inc., Cary, NC) was used for all statistical analyses. For data in Table 1, the fixed effects included prepartal diet, LPS, and diet $\times$ LPS. For data in Table 2 and all figures, the fixed effects included prepartal diet, day (or hour), and the interaction of diet $x$ day (diet $\times$ hour). The random effect in all these analyses was cow within diet. A repeated-measures analysis using an autoregressive order $1[\mathrm{AR}(1)]$ covariance structure was used in all these analyses. Each variable of interest was evaluated for normal distribution using the Shapiro-Wilk test (SAS Institute Inc.) and normalized by natural logarithmic transformation when necessary before statistical analysis. All means were compared using the PDIFF statement of SAS (SAS Institute Inc.), and significant differences were declared at $P \leq 0.10$ with tendencies at $P$-values between 0.11 and 0.15 .

\section{RESULTS}

\section{Acute Response to LPS}

In the absence of data for cows in CON-NC and OVE-NC beyond what was published by Graugnard et al. (2012), we elected to measure mRNA expression of target genes in liver tissue to determine effects of inflammation induced by LPS. Thus, for this analysis, we used cows in CON-LPS, OVE-LPS, CON-NC, and OVE-NC using liver tissue harvested at $2.5 \mathrm{~h}$ post-LPS (Table 1 ). In addition, we measured the concentration of several metabolites in blood serum before LPS $(0 \mathrm{~h})$ and at 2,6 , and $12 \mathrm{~h}$ post-LPS to determine acute changes induced by inflammation due to LPS (Figure 1).

Table 1 shows changes in metabolic- and inflammation-related gene expression at approximately 2.5 $\mathrm{h}$ post-LPS in OVE and CON cows with (CON-LPS, OVE-LPS) and without LPS (CON-NC, OVE-NC). We observed a diet $\times \operatorname{LPS}(P \leq 0.05)$ interaction for the expression of HMGCS2 and XBP1. In the case of $H M G C S 2$, the interaction was due to upregulation with CON-LPS versus CON-NC and downregulation with OVE-LPS versus OVE-NC. For XBP1, the interaction resulted from marked upregulation in expression with OVE-LPS compared with OVE-NC. We found an overall effect of $\operatorname{diet}(P=0.06)$ for the expression of $A C O X 1$ due to greater values observed with OVE-NC and OVE-LPS cows. We observed an overall LPS effect $(P$ $<0.06)$ that was associated with marked upregulation of inflammation- and stress-related genes; that is, TNF, NFKB1, TLR4, SOD2, PERK, and ANGPTL4. In addition, the overall LPS effect $(P=0.05)$ for DGAT1 and PPARD was due to upregulation in nonchallenged cows compared with the LPS groups.

Figure 1 shows the temporal changes in rectal temperature and plasma concentrations of NEFA, BHBA, TAG, and bilirubin before $(0 \mathrm{~h})$ and during the first 12 h post-LPS challenge. Temperature did not differ $(P>$ $0.10)$ between prepartal dietary treatments; however, an obvious and expected temperature increase occurred after LPS (time, $P<0.05$ ), which peaked at $6 \mathrm{~h}$. The concentrations of NEFA and TAG increased $(P<0.05)$ regardless of diet by $2 \mathrm{~h}$ postchallenge, after which concentrations returned to baseline values. In contrast to NEFA and TAG, blood BHBA concentration gradually decreased $(P<0.05)$, regardless of prepartal diet. Bilirubin increased $(P<0.05) 2 \mathrm{~h}$ after LPS regardless of prepartal diet and remained unchanged until the last sampling time at $12 \mathrm{~h}$. At the mammary gland level, 
Table 1. Acute changes in hepatic mRNA expression (log-scale; $\mathrm{n}=6 /$ treatment) in cows fed a control diet (1.34 Mcal $/ \mathrm{kg}$ of $\mathrm{DM})$ or a moderate-energy diet (1.62 Mcal/kg of DM) during the entire dry period with (CON-LPS, OVE-LPS) or without (CON-NC, OVE-NC) an intramammary LPS challenge (CON-LPS, OVE-LPS) at $7 \mathrm{~d}$ postpartum. Liver tissue was collected $2.5 \mathrm{~h}$ after LPS challenge

\begin{tabular}{|c|c|c|c|c|c|c|c|c|}
\hline Gene & \multicolumn{4}{|c|}{ Treatment } & $\mathrm{SEM}^{1}$ & \multicolumn{3}{|c|}{$P$-value } \\
\hline \multicolumn{9}{|l|}{ Metabolism } \\
\hline PPARA & 0.16 & -0.37 & -0.22 & -0.32 & 0.22 & 0.12 & 0.43 & 0.29 \\
\hline PPARD & -0.37 & -0.24 & 0.15 & 0.24 & 0.23 & 0.67 & 0.05 & 0.93 \\
\hline$A C O X 1$ & -0.75 & -0.09 & -0.26 & -0.12 & 0.20 & 0.06 & 0.29 & 0.24 \\
\hline \multicolumn{9}{|c|}{ Inflammation and stress } \\
\hline$T N F$ & -0.24 & -0.02 & 0.79 & 0.83 & 0.31 & 0.68 & 0.01 & 0.79 \\
\hline NFKB1 & -0.68 & -0.25 & 0.67 & 0.63 & 0.25 & 0.46 & 0.01 & 0.39 \\
\hline ANGPTL4 & -0.96 & 0.33 & 1.25 & 1.09 & 0.46 & 0.25 & 0.01 & 0.14 \\
\hline TLR4 & -1.41 & -0.64 & 1.37 & 1.23 & 0.33 & 0.37 & 0.01 & 0.19 \\
\hline SOD2 & -0.05 & -0.11 & 0.47 & 0.37 & 0.24 & 0.77 & 0.06 & 0.94 \\
\hline PERK & -0.19 & -0.13 & 0.55 & 0.33 & 0.22 & 0.73 & 0.01 & 0.55 \\
\hline
\end{tabular}

${ }^{1}$ Largest SEM is shown.

we observed a marked increase in milk SCC in the challenged rear quarter at the first milking post-LPS, which continued to increase to at least the third milking postLPS (Figure 1). Subsequently, concentrations of SCC decreased dramatically by d 4 post-LPS, at which point SCC were $<200,000$ cells $/ \mathrm{mL}$.

\section{Performance}

Analysis of BW, BCS, and performance data at defined portions of the prepartal and postpartal periods (Table 2) was done to focus on critical time points for metabolic changes in the cow (Dann et al., 2005; Janovick and Drackley, 2010; Janovick et al., 2011). Average BW and BCS during the last 4 wk prepartum were greater $(P<0.05)$ in OVE than in CON cows (Table 2). Postpartal BCS did not differ $(P>0.10)$ with diet. However, BCS decreased $(P<0.05)$ between wk 1 and 6 after parturition. As expected, energy balance (Mcal/d or \% of requirements) during the last 4 wk prepartum was greater $(P<0.05)$ in OVE cows. We also observed clear differences between OVE and CON in energy balance during wk 1 after parturition and before LPS challenge; that is, cows in CON were in more positive energy balance $(P<0.05)$. We observed an overall increase (day, $P<0.05$ ) in energy balance between wk 2 and 6 regardless of diet.

Average DMI (\% or $\mathrm{kg} / \mathrm{d}$ ) over the last 4 wk prepartum did not differ $(P>0.10)$ between OVE and CON (Table 2). We observed greater DMI (as \% of BW) during the first $41 \mathrm{~d}$ postpartum in CON cows (Table $2)$. The overall intake of $\mathrm{DM}(\mathrm{kg} / \mathrm{d})$ was similar for both groups; thus, differences in DMI as a percentage of $\mathrm{BW}$ were caused by lower $\mathrm{BW}$ in $\mathrm{CON}$ compared with OVE (Table 2). Both groups increased DMI (kg/d or as \% of BW) gradually over time $(P<0.05$; Figure $2)$. Milk yield also increased $(P<0.05$; Figure 2$)$ for both groups from 7 to 41 DIM, with no differences between diets; diets did not differ in milk fat percentage, resulting in similar FCM yield and apparent energetic efficiency. Calf birth weight was not affected $(P>0.10)$ by prepartal dietary energy level.

\section{Lipid and TAG Accumulation in Liver}

Liver tissue from cows in CON-NC and OVE-NC (Graugnard et al., 2012), as well as in CON-LPS and OVE-LPS, at $-14,7$ (2.5 h post LPS), 14, and $30 \mathrm{~d}$ relative to calving was used to generate additional data to evaluate the potential interaction of diet with LPS and of LPS alone on liver lipidosis. Figure 3 shows the concentrations of liver lipid and TAG before and after parturition in cows receiving CON-LPS, OVE-LPS, CON-NC, or OVE-NC. We observed an overall effect of diet $(P=0.001)$ on the concentration of lipid and TAG due to the greater response observed in OVELPS cows. Such a response was evident for TAG at 7 $\mathrm{d}$, when the concentration averaged approximately $5 \%$ in OVE-LPS cows compared with $1.5 \%$ in the other groups. Subsequently, both OVE groups had greater concentrations of TAG at $14 \mathrm{~d}$; for OVE-LPS cows, the concentration remained greater than other treatments at $30 \mathrm{~d}$.

\section{Metabolic and Oxidative Stress Indices in Blood}

Blood serum from cows in CON-LPS and OVE-LPS harvested at $-14,7$ (2.5 h post LPS), 14, and $30 \mathrm{~d}$ relative to calving was used to evaluate the carryover effect of prepartal dietary energy feeding on markers of 
Table 2. Dry matter intake, milk production, BW, BCS, and energy balance in cows $(\mathrm{n}=9 /$ diet $)$ fed a control diet (CON, $1.34 \mathrm{Mcal} / \mathrm{kg}$ of $\mathrm{DM})$ or a moderate-energy diet (OVE; $1.62 \mathrm{Mcal} / \mathrm{kg}$ of DM) during the entire dry period and an intramammary LPS challenge at $7 \mathrm{~d}$ postpartum

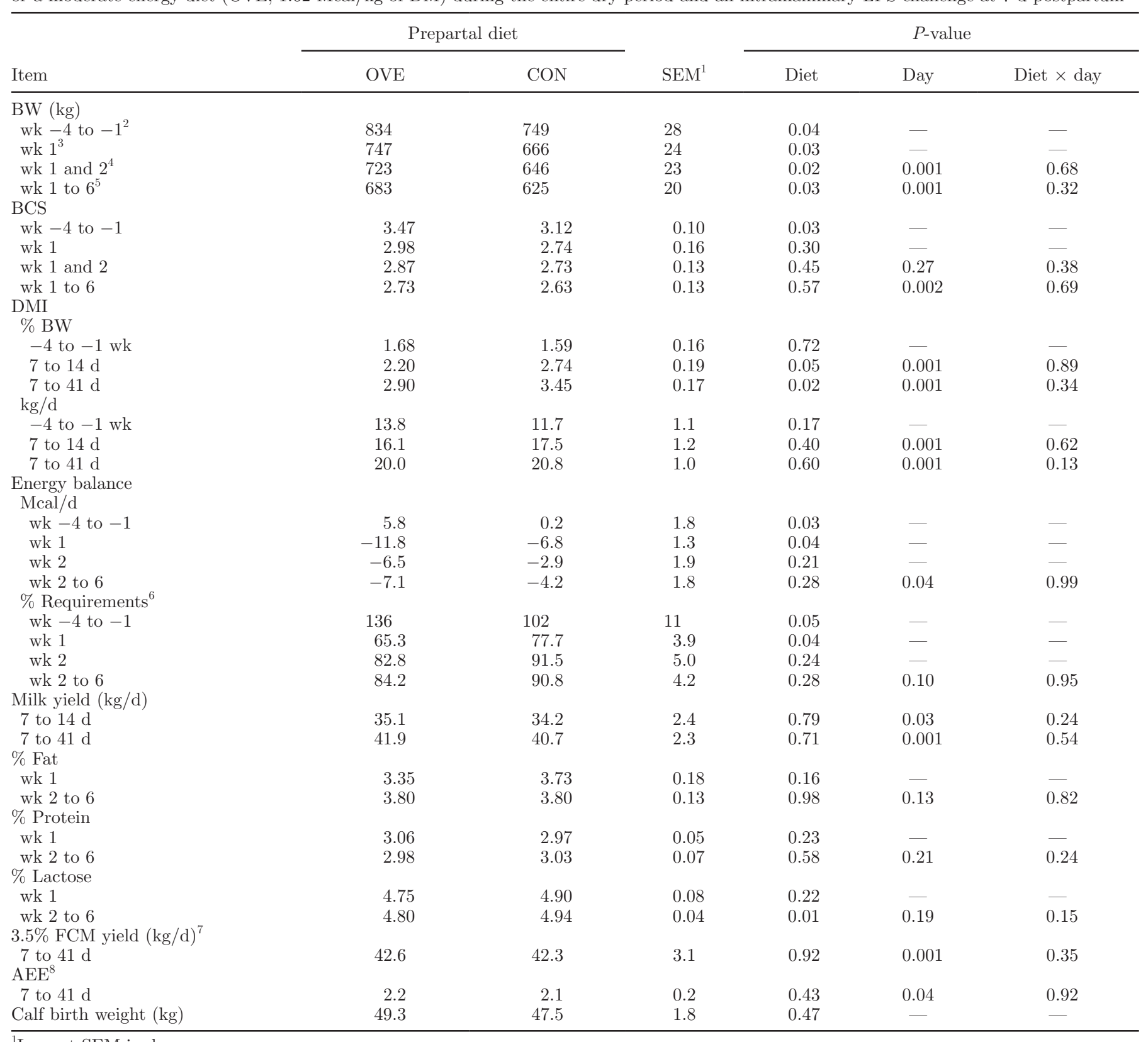

${ }^{1}$ Largest SEM is shown.

${ }^{2}$ Encompasses the first half of the peripartal period.

${ }^{3}$ Encompasses the period after calving and before the LPS challenge.

${ }^{4}$ Encompasses the first week after LPS challenge to examine the short-term response to LPS.

${ }^{5}$ Encompasses the 5 wk after LPS challenge to examine the longer-term response to LPS.

${ }^{6}$ Percentage of NRC (2001) requirements.

${ }^{7} 3.5 \%$ FCM, $\mathrm{kg}=$ milk yield, $\mathrm{kg} \times[(0.4324)+(16.218 \times$ fat $\% \times 0.01)]$.

${ }^{8}$ Apparent energetic efficiency $=3.5 \%$ FCM $(\mathrm{kg})$ divided by DMI $(\mathrm{kg})$.

metabolism, inflammation, and oxidative stress after an inflammatory challenge. Figure 4 shows blood serum concentrations of NEFA, BHBA, glucose, insulin, creatinine, ROM, TAG, and urea. Concentration of
NEFA decreased $(P<0.05)$ in CON-LPS but increased slightly or remained unchanged in OVE-LPS cows between 7 and $21 \mathrm{~d}$ postpartum, resulting in a diet $\times$ day response $(P<0.05)$. Concentration of BHBA decreased 

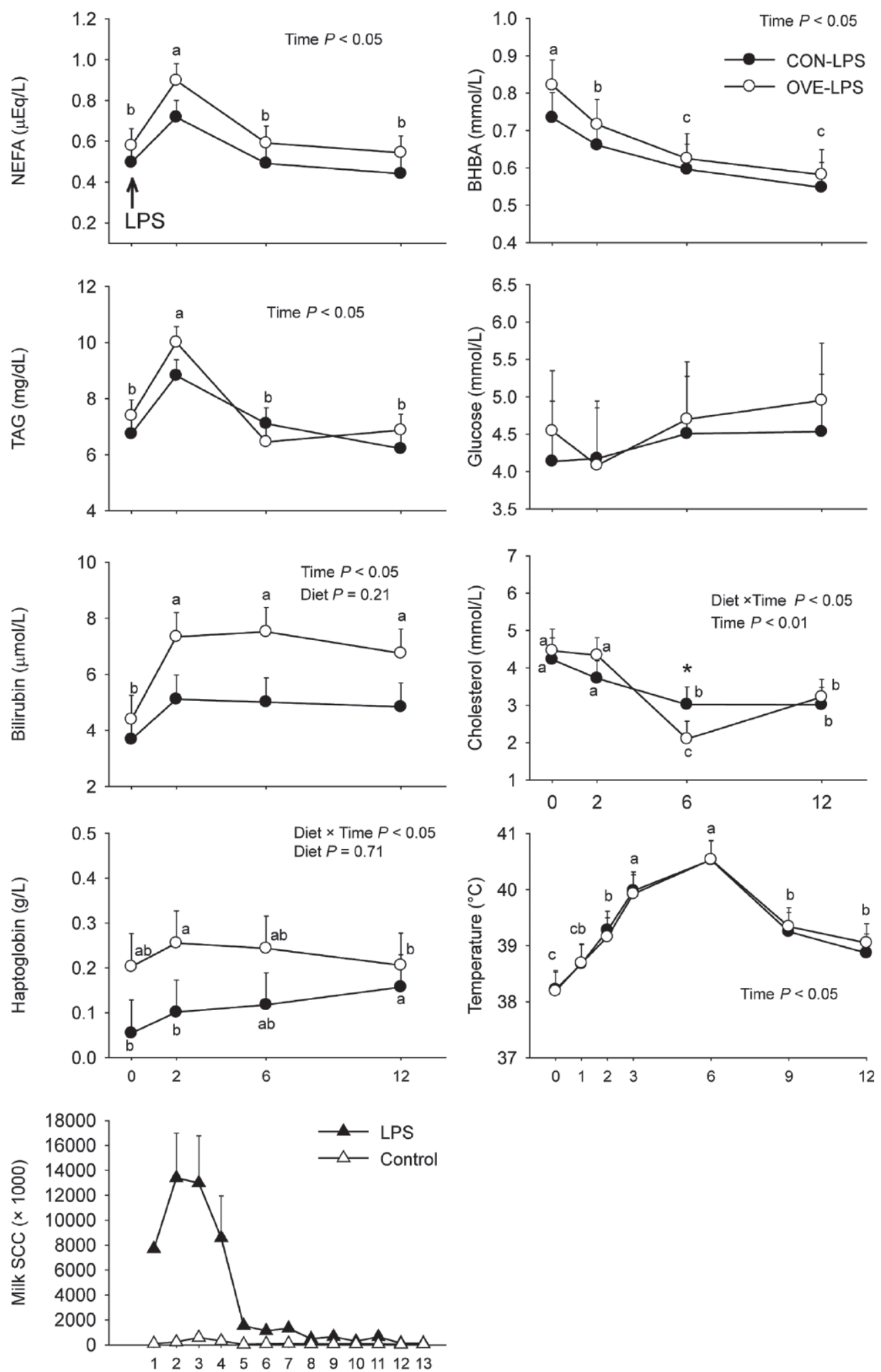

Hour/milking relative to LPS challenge

Figure 1. Acute changes in plasma concentrations of metabolic and inflammatory indicators and rectal temperature $(\mathrm{n}=9 / \mathrm{diet})$, and milk $\mathrm{SCC}$ in cows fed a control diet (CON; $1.34 \mathrm{Mcal} / \mathrm{kg}$ of DM) or a moderate-energy diet (overfed, OVE; $1.62 \mathrm{Mcal} / \mathrm{kg}$ of DM) during the entire dry period and an intramammary LPS challenge (CON-LPS, OVE-LPS, respectively) at 7 DIM. Sample at d 7 was collected before LPS challenge. ${ }^{\mathrm{a}-c}$ Differences between diets $(P<0.05) ;{ }^{*}$ diet $\times$ time $(P \leq 0.10)$. TAG $=$ triacylglycerol. 

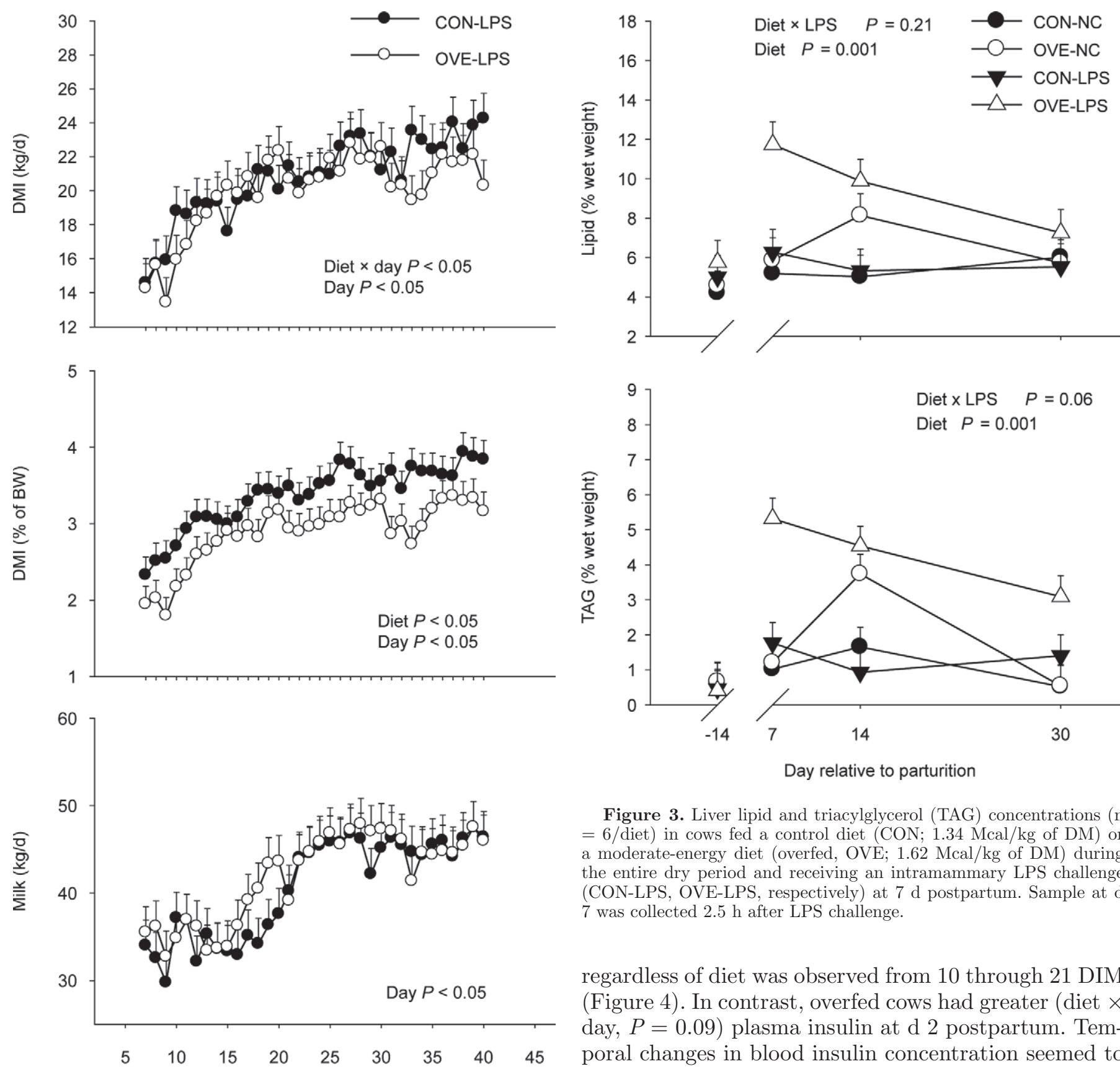

Day relative to parturition

Figure 2. Daily DMI and milk production in cows $(\mathrm{n}=9 /$ diet $)$ fed a control diet (CON; $1.34 \mathrm{Mcal} / \mathrm{kg}$ of $\mathrm{DM})$ or a moderate-energy diet (overfed, OVE; $1.62 \mathrm{Mcal} / \mathrm{kg}$ of DM) during the entire dry period and receiving an intramammary LPS challenge (CON-LPS, OVE-LPS, respectively) at $7 \mathrm{~d}$ postpartum on liver lipid and triglyceride concentrations.

(day, $P<0.05$ ) between $\mathrm{d} 2$ and 14 regardless of diet, and then increased to concentrations close to prepartal values by $\mathrm{d} 21$.

Glucose concentration remained constant from 2 to 7 DIM after which a significant increase (day, $P<0.05$ )

gardless of diet was observed from 10 through 21 DIM (Figure 4). In contrast, overfed cows had greater (diet $x$ day, $P=0.09)$ plasma insulin at d 2 postpartum. Temporal changes in blood insulin concentration seemed to reflect changes in blood glucose with a marked increase (day, $P<0.05$ ) from 7 to 10 DIM.

Overall, the concentration of ROM was greater (diet, $P<0.06)$ for OVE-LPS than for CON-LPS, due primarily to greater values at 10 and 14 DIM. Although control cows had greater (diet $\times$ day, $P<0.05$ ) creatinine concentration at $2 \mathrm{~d}$ postpartum, creatinine decreased over time $(P<0.05)$ in both groups to a nadir at 10 DIM.

The concentration of TAG decreased (day, $P<0.05$ ) gradually from d 2 to 21 after parturition in both groups. In addition, cows in the CON group tended $(P$ $=0.11$ ) to have overall greater concentration of urea, 
which decreased (day, $P<0.05$ ) in both groups from d 7 to 14 followed by a return to basal (i.e., pre-LPS) concentrations by $\mathrm{d} 21$.

\section{Liver Function and Inflammation Indices in Blood}

Figure 5 shows concentrations of cholesterol, albumin, ceruloplasmin, haptoglobin, GOT, and bilirubin. Cholesterol concentration was greater (diet $\times$ day, $P<$ 0.05) in OVE-LPS than in CON-LPS at 10 and 14 DIM, but the trend in both groups was for a gradual increase through 21 DIM. Albumin concentration was greater at 2 and 21 DIM in CON-LPS, resulting in a significant interaction $(P<0.05)$. Regardless of dry period diet, ceruloplasmin concentration increased gradually (day, $P<0.05$ ) from 2 to 10 DIM; subsequently, the ceruloplasmin was constant until 21 DIM. Furthermore, OVE-LPS cows had greater (diet, $P=0.08$ ) ceruloplasmin concentrations during the 21-d postpartal period. Concentrations of haptoglobin increased (day, $P<0.05$ ) between 7 and 10 DIM regardless of diet, and then decreased by d 14 to 21 to values below those observed at 2 and 7 DIM. Concentration of both GOT and bilirubin decreased (day, $P<0.05$ ) gradually, regardless of diet, by 10 to 21 DIM. Regardless of dry period diet, vitamin $\mathrm{A}$, vitamin $\mathrm{E}$, and $\beta$-carotene concentrations increased (day, $P<0.05$ ) over time (Figure 6 ). The overall vitamin E response was greater $(P=0.09)$ in the OVE-LPS group, mainly due to differences at 10, 14, and 21 DIM.

\section{Hepatic Gene Expression}

With the exception of PCK1, PC, PDHA1, HP, SOCS2, and SAA3, we observed no main effects of diet or diet $x$ day effects for the expression of any of the genes associated with metabolism, acute-phase response, stress and inflammation, GH/IGF1 axis, or control of gene transcription (Figures 7, 8, and 9). At 14 DIM, hepatic $P C$ expression was lower (diet $\times$ day, $P<0.05)$ for CON-LPS compared with OVE-LPS cows; however, at $30 \mathrm{DIM}$, the expression of PDHA1 and $P C K 1$ was lower (diet $\times$ day, $P<0.08$ ) for OVELPS compared with CON-LPS cows.

Among genes associated with fatty acid oxidation (Figure 7), we observed no changes $(P>0.10)$ in expression over time for $C P T 1 A$ and $H M G C S 2$; however, expression of ACOX1 and PPARA decreased (day, $P$ $<0.05)$ between -14 and $7 \mathrm{~d}$, after which expression returned to prepartal levels. With regard to genes associated with gluconeogenesis and the oxidation of glucose, $P C$ and PDHA1 expression increased (diet $\times$ day, $P=0.02$ ) markedly, regardless of diet, between -14 and $7 \mathrm{~d}$. Subsequently, expression of $P C$ was greater in OVE-LPS cows at $14 \mathrm{~d}$ but expression of PDHA1 was lower at $30 \mathrm{~d}$. The temporal pattern of $P C K 1, P C$, and
PDHA1 expression in OVE-LPS cows revealed gradual downregulation between $\mathrm{d} 7$ and 30 postpartum. In CON-LPS cows, however, the expression of those genes did not change appreciably after $14 \mathrm{~d}$.

Genes associated with the acute phase response and oxidative stress are shown in Figure 8. Expression of $S A A 3$ and $H P$ increased markedly between -14 and $7 \mathrm{~d}$, similarly to TNF, IRAK1, MYD88, ANGPTL4, and the antioxidant enzyme SOD2. Despite a gradual decrease in expression of HP between 7 and $30 \mathrm{~d}$, OVE-LPS compared with CON-LPS cows had greater (diet $\times$ day, $P=0.09$ ) expression at 14 and $30 \mathrm{~d}$. The expression of $S A A 3$ was greater (diet $\times$ day, $P<0.05$ ) in CON-LPS compared with OVE-LPS cows at 7 DIM (i.e., $2.5 \mathrm{~h}$ postchallenge). Except for ANGPTL4 and HP in OVELPS cows, expression of the above genes returned to prepartal levels by 30 DIM, regardless of diet.

As expected, serum concentrations of $\mathrm{GH}$ increased around parturition $(P<0.05)$ for all cows, and concentrations were greater in CON than OVE cows at 0 and 2 DIM (i.e., before LPS challenge; Figure 9). In contrast, blood serum concentration of IGF-1 was greater (diet $\times$ day, $P=0.01$ ) at -14 and $0 \mathrm{~d}$ for OVE compared with CON cows. However, diet and diet $\times$ day did not alter $(P>0.10)$ the expression of GHR and IGF1 in liver throughout the study period. Although expression of STAT5B and SOCS2 did not differ prepartum with treatment, the overall expression of SOCS2 was lower (diet, $P=0.02$ ) in OVE cows primarily due to a decrease in expression (day, $P=0.07$ ) between 7 and 14 DIM.

Among the genes associated with lipid metabolism (Table S5 in supplemental materials; http://www. journalofdairyscience.org/), the expression of DGAT1 increased (day, $P<0.05$ ) between -14 and $7 \mathrm{~d}$, but that of FAAH and MTTP decreased during the same period. In the case of $M T T P$, expression was higher at -14 compared with $30 \mathrm{~d}$. Among the stress and inflammation-related genes (Supplemental Table S5; http://www.journalofdairyscience.org/), PERK expression was lower (day, $P<0.05$ ) at $7 \mathrm{~d}$ and increased gradually to highest values at $30 \mathrm{~d}$, whereas expression of $X B P 1$ increased (day, $P<0.05$ ) markedly at 7 compared with $-14 \mathrm{~d}$ and then decreased gradually through $30 \mathrm{~d}$ (Table S5 in supplemental materials). Among the transcription regulators evaluated, expression of NFKB1, CREB3L3, and PPARD increased (day, $P<0.05)$ dramatically between -14 and $7 \mathrm{~d}$ and then decreased at 14 and $30 \mathrm{~d}$.

\section{DISCUSSION}

\section{Short-Term Response to LPS}

The combined data on liver gene expression (Table 1), the 12-h blood metabolite analysis (Figure 1), and 

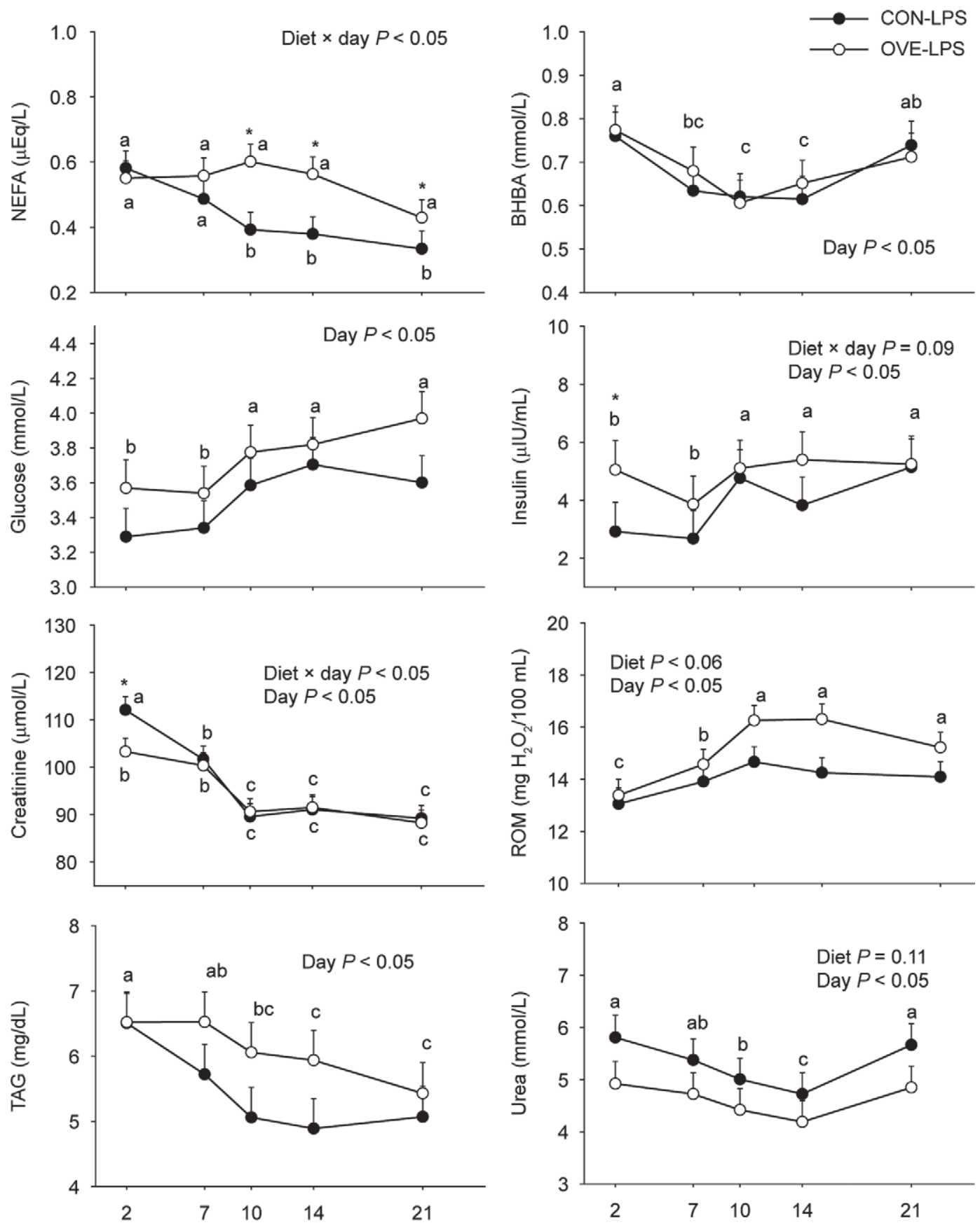

Day relative to parturition

Figure 4. Blood concentration of metabolic indicators $(\mathrm{n}=9 /$ diet $)$ in cows fed a control diet (CON; $1.34 \mathrm{Mcal} / \mathrm{kg}$ of DM) or a moderateenergy diet (overfed, OVE; $1.62 \mathrm{Mcal} / \mathrm{kg}$ of DM) during the entire dry period and receiving an intramammary LPS challenge at $7 \mathrm{~d}$ postpartum. Sample at $\mathrm{d} 7$ was collected before LPS challenge. ${ }^{\mathrm{a}-\mathrm{c}}$ Differences between days $(P<0.05) ;{ }^{*}$ diet $\times$ day $(P \leq 0.10)$. TAG $=$ triacylglycerol; ROM $=$ reactive oxygen metabolites.

liver composition at $2.5 \mathrm{~h}$ post-LPS (Figure 3) provide some evidence of acute effects of LPS on adipose lipolysis, ketogenesis, lipidosis, and liver function (e.g., bilirubin clearance, haptoglobin). Similar results for NEFA and BHBA were observed in cows infused i.v. with LPS during mid lactation (Waldron et al., 2003). Bacterial LPS elicits an inflammatory response (e.g., increased blood tumor necrosis factor, TNF), leading to elevated circulating levels of NEFA as a result of enhanced adipose lipolysis ( $\mathrm{Zu}$ et al., 2009). Although 

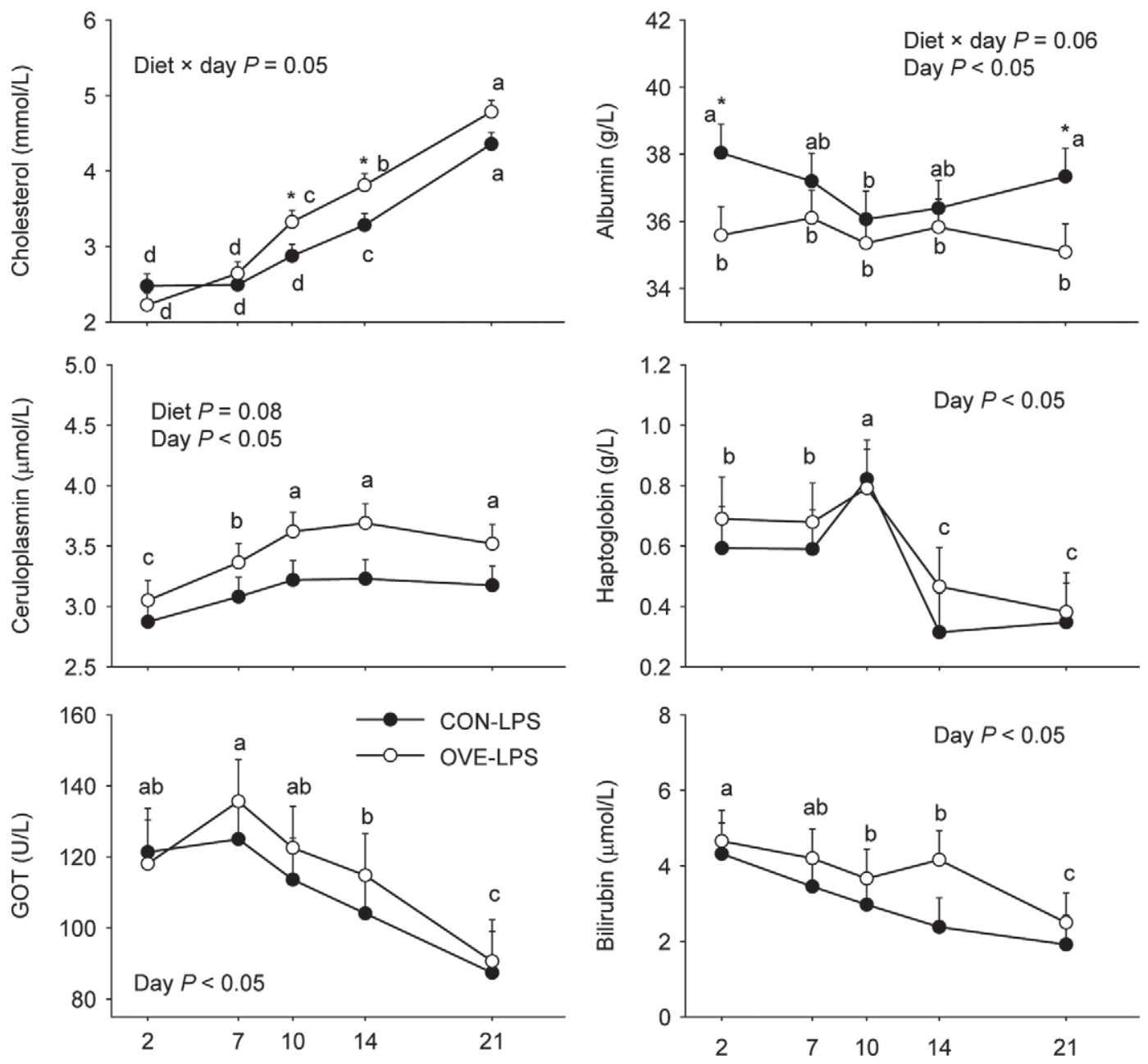

Day relative to parturition

Figure 5. Blood concentration of indicators of inflammation and liver function in cows ( $\mathrm{n}=9 /$ diet) fed a control diet (CON; $1.34 \mathrm{Mcal} /$ $\mathrm{kg}$ of DM) or a moderate-energy diet (overfed, OVE; $1.62 \mathrm{Mcal} / \mathrm{kg}$ of DM) during the entire dry period and receiving an intramammary LPS challenge at $7 \mathrm{~d}$ postpartum (CON-LPS, OVE-LPS, respectively). Sample at d 7 was collected before LPS challenge. ${ }^{\text {a-d }}$ Differences between days $(P<0.05) ; *$ diet $\times$ day $(P \leq 0.10)$. GOT $=$ glutamic oxalacetic transaminase.

the possibility of greater BHBA utilization cannot be discounted, these and previous data (Waldron et al., 2003) seem to suggest that ketogenesis (at least in the short term) may have been impaired by LPS-induced inflammation, an effect that has been clearly demonstrated in nonruminants (Khovidhunkit et al., 2004).

The increase in bilirubin concentration (an index of liver function; Bionaz et al., 2007) as a consequence of inflammation in nonruminants appears to be caused by the proinflammatory cytokine IL- $1 \beta$, which activates the transcription factor nuclear factor $\kappa \mathrm{B} 1$ that regulates mRNA expression of key hepatic enzymes involved in bilirubin clearance (Assenat et al., 2004). The results from our study, including those related to haptoglobin, are similar to those reported by Bionaz et al. (2007), in which plasma bilirubin was highest (10.1 vs. $6.2 \pm$ $0.6 \mu \mathrm{mol} / \mathrm{L}$ ) in cows classified retrospectively as having impaired liver function.

\section{Performance Effects Caused by Prepartal Energy}

Our performance data (Table 2, Figure 2) are similar to those reported in previous experiments (Douglas et al., 2006; Janovick and Drackley, 2010) in cows fed to meet or exceed prepartal energy requirements $(\sim 100$ to $150 \%$ of NRC requirements). Together, our performance data during the first approximately $6 \mathrm{wk}$ postpartum showed no benefit of prepartal overconsumption of energy and demonstrated evidence of more severe NEB early postpartum. 

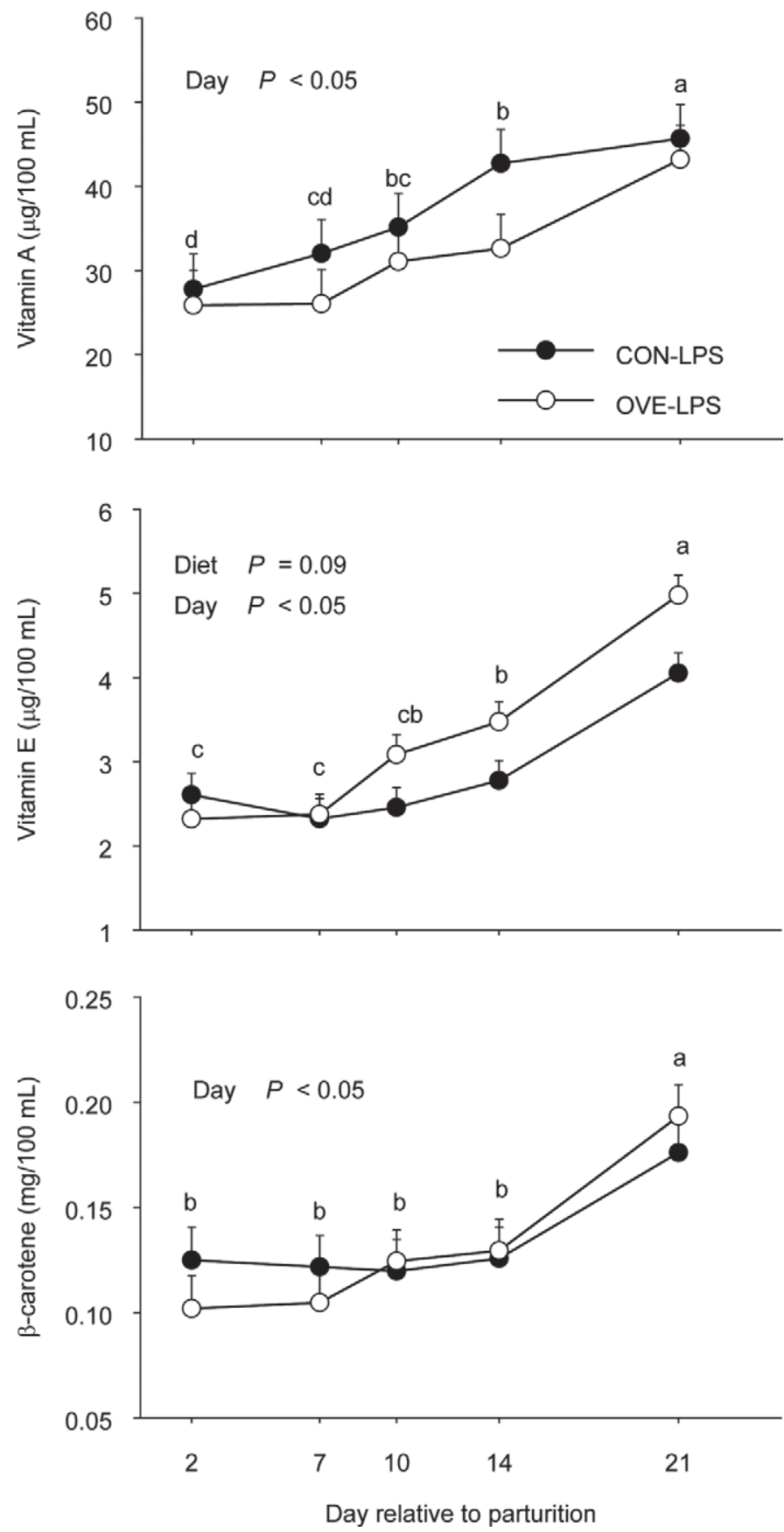

Figure 6. Blood concentration of selected vitamins and provitamins in cows $(\mathrm{n}=9 /$ diet $)$ fed a control diet $(\mathrm{CON} ; 1.34 \mathrm{Mcal} / \mathrm{kg}$ of DM) or a moderate-energy diet (overfed, OVE; $1.62 \mathrm{Mcal} / \mathrm{kg}$ of DM) during the entire dry period and receiving an intramammary LPS challenge at $7 \mathrm{~d}$ postpartum (CON-LPS, OVE-LPS, respectively). Sample at d 7 was collected before LPS challenge. ${ }^{\mathrm{a}-\mathrm{d}}$ Differences between days $(P<0.05)$.

\section{Liver Lipid Composition}

The concentration of total lipid in liver observed in OVE-LPS cows was similar to that in cows classified as having fatty liver ( $\sim 8 \%$ to $11 \%$ total lipid) during the first 3 wk postpartum (Ametaj et al., 2005). Control and CON-LPS cows had similar total liver lipid as healthy controls in the study of Ametaj et al. (2005). Several mechanisms can be proposed to explain these different responses to LPS between diets. First, overfeeding during the dry period leads to overconditioning (i.e., excessive adipose tissue deposition), greater BCS before calving, and a more marked reduction in appetite around calving (Hayirli et al., 2002). As a consequence, prepartal overconditioned dairy cows often are in more severe NEB than cows with a normal BCS (Rukkwamsuk et al., 1999; Hayirli et al., 2002), which is in line with what we observed (Table 2). Under such conditions, it is likely that the capacity of liver to maintain the balance between export of TAG in very low density lipoprotein (VLDL) with hepatic TAG synthesis is inadequate, resulting in TAG accumulation (Drackley et al., 2005). Our observations that overfeeding energy prepartum led to greater accumulation of TAG in liver soon after LPS challenge (and in the longer term) is in line with blood metabolic indicators of liver lipid metabolism; that is, OVE-LPS cows had greater blood NEFA between 10 and 21 DIM and numerically greater TAG between 10 and 14 DIM, but had a similar decrease in blood BHBA than CON-LPS between 7 and 14 DIM (Figure 4). Together, these data suggest greater impairment of liver lipid metabolism due to inflammatory challenge in overfed cows.

Previous studies have examined blood markers of inflammation in response to endotoxin or E. coli mastitis early postpartum (Hoeben et al., 2000) and blood markers of inflammation and liver TAG concentrations after LPS treatment immediately postcalving (Bertoni et al., 2006). We are unaware of studies with early postpartal cows that have examined any link between liver lipid accumulation in response to LPS or endotoxin challenge and prepartal feeding management. However, evidence exists of increased plasma NEFA concentrations following LPS infusion (Waldron et al., 2003) or TNF administration (Kushibiki et al., 2003), of reduced peripheral insulin sensitivity (Vernay et al., 2012), and of liver TAG accumulation following s.c. TNF in midlactation cows (Bradford et al., 2009). Our data suggest that the inflammatory challenge in prepartal energyoverfed cows elicited a sustained lipolytic response, hence favoring higher concentrations of NEFA in the circulation and resulting in persistent TAG accumulation during early lactation.

\section{Markers of Inflammation and Oxidative Stress in Blood}

Overall, the blood data on inflammatory and oxidative stress markers were suggestive of a chronic altera- 

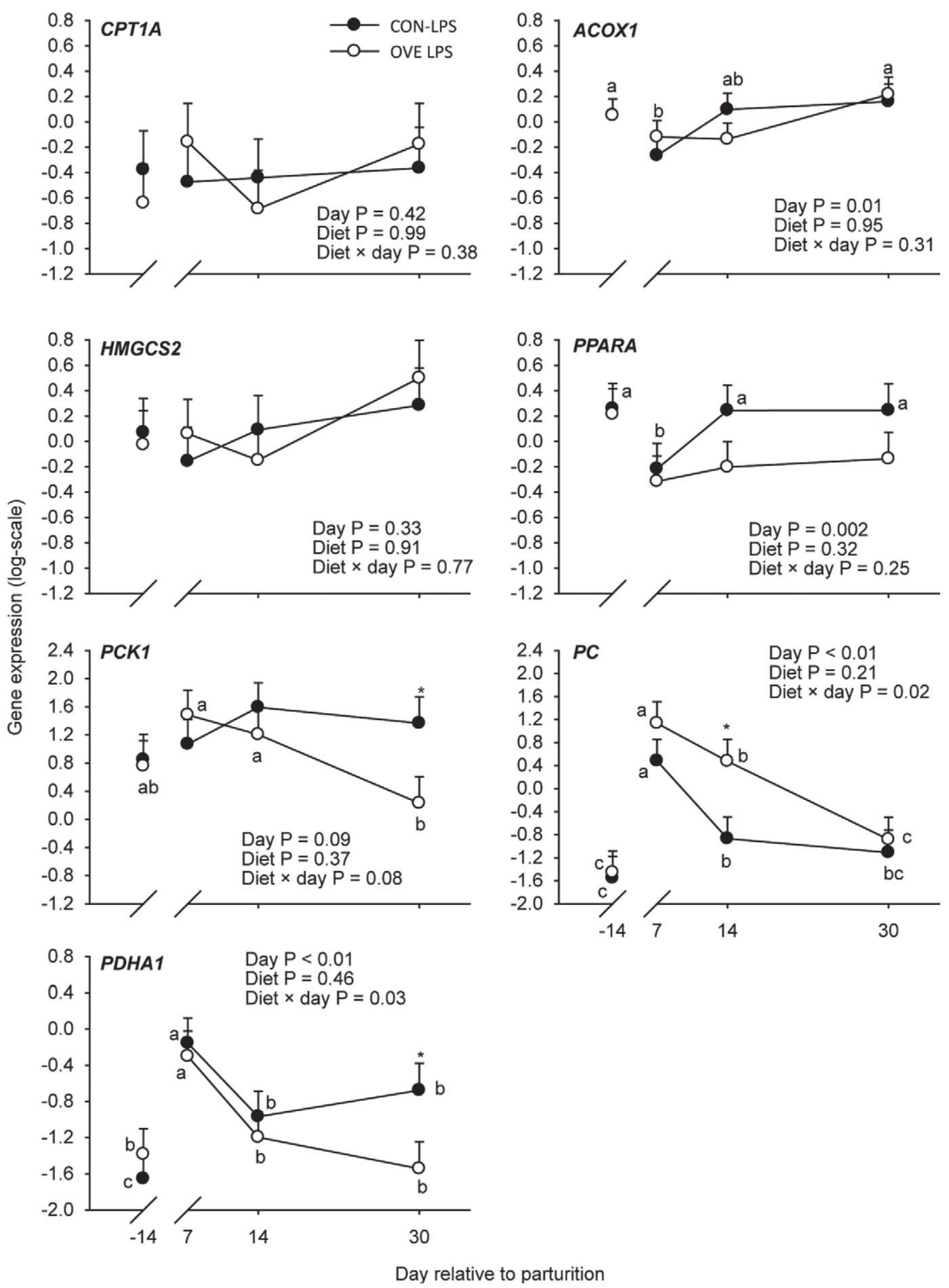

Figure 7. Hepatic mRNA expression of genes associated with fatty acid oxidation (CPT1A, ACOX1, HMGCS2, PPARA), gluconeogenesis $(P C K 1, P C)$, and glucose oxidation $(P D H A 1)$ in cows $(\mathrm{n}=6 /$ diet $)$ fed a control diet (CON; $1.34 \mathrm{Mcal} / \mathrm{kg}$ of DM) or a moderate-energy diet (overfed, OVE; $1.62 \mathrm{Mcal} / \mathrm{kg}$ of DM) during the entire dry period and receiving an intramammary LPS challenge at $7 \mathrm{~d}$ postpartum (CON-LPS, OVE-LPS, respectively). Sample at d 7 was collected $2.5 \mathrm{~h}$ after LPS challenge. ${ }^{\mathrm{a}-\mathrm{c}}$ Differences among days $(P<0.05) ;{ }^{*}$ diet $\times$ day $(P<0.05)$.

tion in liver fatty acid oxidation and ketogenesis in the prepartal energy-overfed cows. The marked increase in hepatic mRNA expression of $T N F$ at approximately
$2.5 \mathrm{~h}$ after LPS challenge (Table 1) likely reflected an acute response to inflammation signals and was in agreement with previous data (Bradford et al., 2009). 

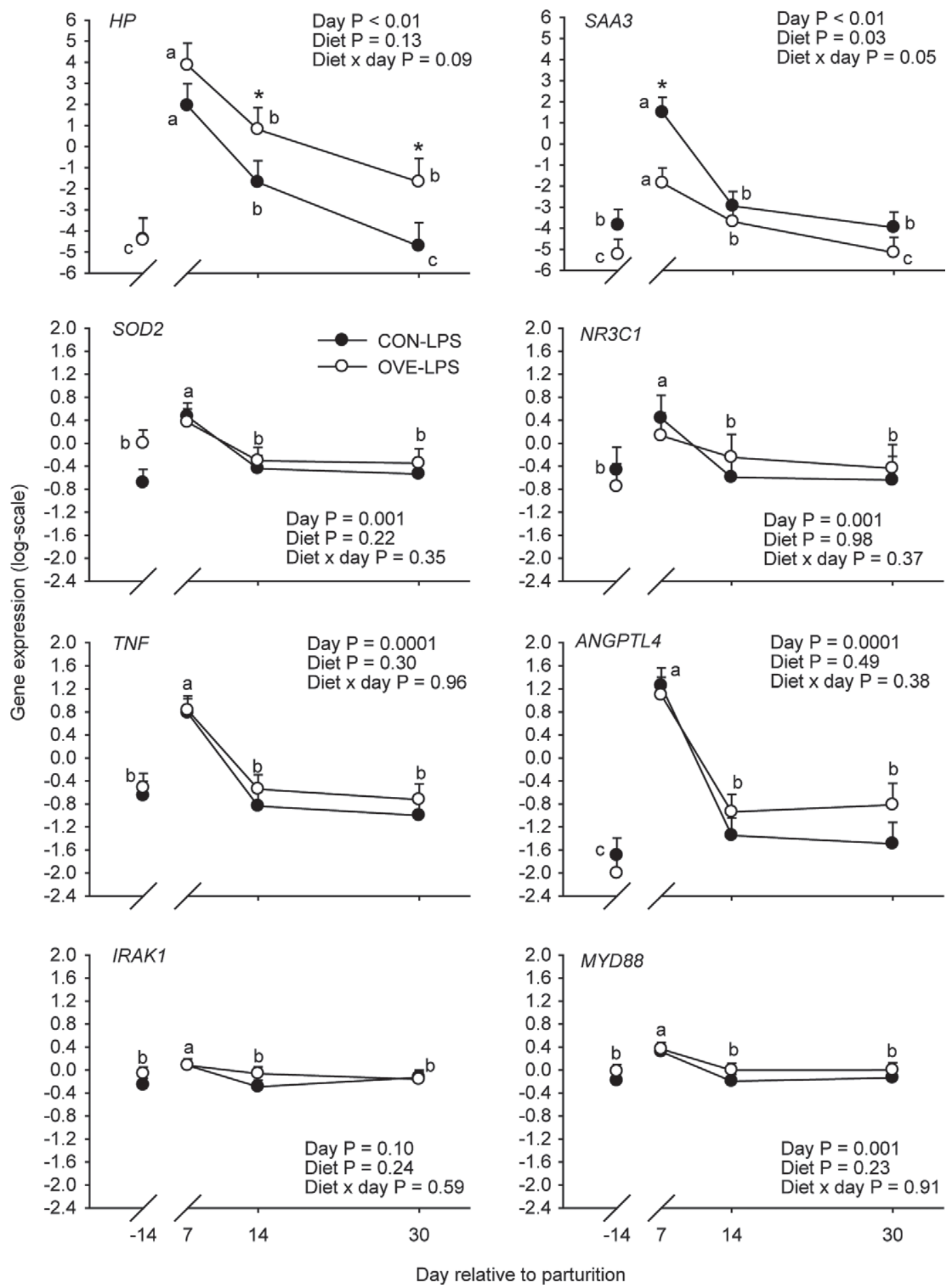

Figure 8. Hepatic mRNA expression of genes associated with acute phase response (HP and SAA3), stress (SOD2, NR3C1), and inflammation (TNF, ANGPTL4, IRAK1, MYD88) in cows (n =6/diet) fed a control diet (CON; $1.34 \mathrm{Mcal} / \mathrm{kg}$ of DM) or a moderate-energy diet (overfed, OVE; $1.62 \mathrm{Mcal} / \mathrm{kg}$ of DM) during the entire dry period and an intramammary LPS challenge at $7 \mathrm{~d}$ postpartum (CON-LPS, OVE-LPS, respectively). Sample at d 7 was collected $2.5 \mathrm{~h}$ after LPS challenge. ${ }^{a-c}$ Differences among days $(P<0.05) ;{ }^{*}$ diet $\times$ day $(P<0.05)$.

Injection of TNF in mid-lactation cows for $7 \mathrm{~d}$ resulted in greater liver TAG concentration (Bradford et al., 2009), without differences in serum NEFA, partly be- cause of the reduction in synthesis of apolipoproteins. It can be speculated that the serum TNF concentration in OVE-LPS compared with CON-LPS cows, as well as 

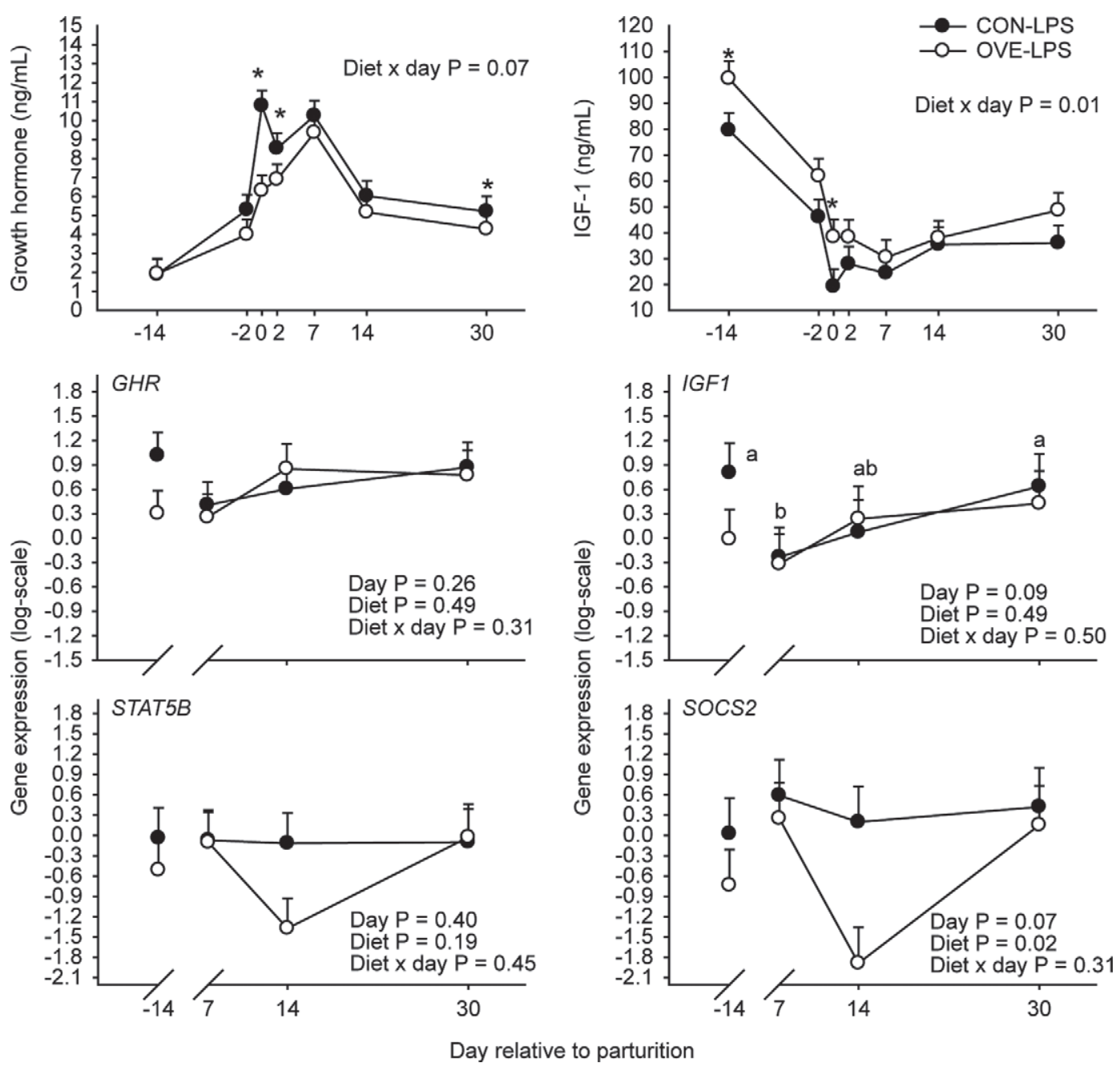

Figure 9. Blood concentration of growth hormone (GH) and IGF-1, and hepatic mRNA expression of GH signaling-related genes (GHR, IGF1, STAT5B, SOCS2) in cows fed a control diet (CON; $1.34 \mathrm{Mcal} / \mathrm{kg}$ of DM) or a moderate-energy diet (overfed, OVE; $1.62 \mathrm{Mcal} / \mathrm{kg}$ of DM) during the entire dry period and an intramammary LPS challenge at $7 \mathrm{~d}$ postpartum (CON-LPS, OVE-LPS, respectively). Blood samples at d 7 were collected before LPS challenge, whereas liver samples were harvested $2.5 \mathrm{~h}$ after LPS challenge. ${ }^{\mathrm{a}, \mathrm{b}}$ Differences among days $(P \leq 0.10)$; $*$ diet $\times$ day $(P \leq 0.10)$.

the insulin-insensitive state caused by LPS challenge (Vernay et al., 2012), might have remained elevated during the subsequent days post-LPS challenge, thus favoring adipose tissue lipolysis (Kushibiki et al., 2003) and partly explaining the higher NEFA concentrations at 10 and $14 \mathrm{~d}$ (Figure 4).

Excess accumulation of ROM can cause cell and tissue injury and it leads to oxidative stress (Sordillo and Aitken, 2009). Cows with greater prepartal BCS, an indirect measure of body fatness, and elevated levels of NEFA at calving are in a more precarious oxidative status (e.g., lower superoxide dismutase activity in blood), rendering them more sensitive to oxidative stress (Bernabucci et al., 2005). Cows in more severe NEB during early lactation also had greater blood ROM levels and inadequate availability of biological antioxidants, and thus were under increased oxidative stress (Pedernera et al., 2010). Our data appeared consistent with the above studies, in that OVE-LPS cows were in more positive energy balance prepartum and more negative EB before the LPS challenge (Table 2), but ROM concentrations between treatments did not differ until after LPS challenge, when OVE-LPS cows also had a greater increase in concentration of NEFA.

\section{Liver Function and Inflammation}

Trevisi et al. (2009) reported lower blood cholesterol in peripartal cows receiving IFN- $\alpha$ than in control cows. The greater temporal concentrations of cholesterol and ceruloplasmin in OVE-LPS cows observed after 7 DIM suggested a more vigorous and sustained acute phase 
response to the LPS challenge, potentially as a counterregulatory mechanism to reach a normal setpoint. This idea is supported by other data (e.g., ROM, NEFA, liver TAG, ceruloplasmin), suggesting that overfeeding energy prepartum placed a greater toll on metabolism. The temporal profile of ROM resembled that of ceruloplasmin, a response similar to those observed in the inflammatory challenge study of Trevisi et al. (2009). This seems to confirm the existence of the interaction between the inflammatory response (indicated by a slow responder index such as ceruloplasmin) and oxidative stress response.

Overall, the blood concentrations of cholesterol, ceruloplasmin, and albumin, regardless of diet, were within a nonpathological range (Bertoni et al., 2008). However, the lower albumin concentration in OVE-LPS compared with CON-LPS cows at 2 and 21 DIM could be taken as an indication of impaired liver function (Ametaj et al., 2005; Cavestany et al., 2005; Bertoni et al., 2008). The sustained increase in blood cholesterol over time in both groups of cows is a typical response in early lactating cows (Cavestany et al., 2005; Bionaz et al., 2007), but the greater response in OVE-LPS cows was puzzling and it is not readily explainable.

Despite the apparent signs of normal liver function regardless of diet, the concentration of haptoglobin at d 2 to 10 in both groups was similar to those observed in postpartal cows with signs of inflammation and low liver function at 7 DIM (Trevisi et al., 2009). However, our data on liver TAG, cholesterol, and haptoglobin do not support a correlation between these parameters as reported by Ametaj et al. (2005) using early postpartal cows classified as healthy or with fatty liver; that is, negative correlations between total liver lipid and cholesterol but positive correlations between total liver lipid and haptoglobin. Likely, the absence of correlations between liver TAG and plasma parameters in the current study seems justified by the moderate liver lipidosis ( $~ 5.5 \%$ of wet weight of TAG, Figure 3$)$. The data on liver TAG and NEFA in OVE-LPS cows do support a positive relationship between both parameters, as observed by Ametaj et al. (2005).

The concentrations of vitamin A (assessed as retinol) observed, regardless of diet, during the first 14 DIM in this study were within the range reported in the study of Trevisi et al. (2009) for animals with different severities of inflammatory phenomena. Concentrations of vitamin E observed during the first 21 DIM were higher than those reported by Bionaz et al. (2007) in peripartal cows, suggesting that cows in our study were likely in adequate vitamin $\mathrm{E}$ status. The overall increase in vitamin A concentration between 7 and 14 DIM suggested that the LPS challenge did not further impair the hepatic response, despite the fact that OVE-LPS cows (as noted above) were apparently under a more stressful state. The temporal increase in vitamin $\mathrm{E}$ in OVE-LPS cows was likely a counter-regulatory mechanism to stop or control the production of ROM (Figure 4). The fact that the temporal pattern of vitamin $\mathrm{E}$ after 7 DIM in OVE-LPS cows resembled that of cholesterol agrees with data showing a positive relationship between both compounds in cows (Trevisi et al., 2010).

\section{Metabolic Gene Expression in Liver}

In nonruminants, the nuclear receptor PPARA is considered the master regulator of hepatic lipid metabolism during fasting or undernutrition (Kersten et al., 1999). Activation of PPARA promotes uptake, utilization, and catabolism of long-chain fatty acids (LCFA) via coordinated upregulation of CPT1A, ACOX1, and HMGCS2, among other genes (Loor et al., 2005; Selberg et al., 2005). Evidence shows that PPARA activation can regulate inflammation partly by neutralizing and promoting the degradation of leukotriene $\mathrm{B}_{4}$ in both neutrophils and macrophages (Pyper et al., 2010). Although a recent study with dairy calves reported no change in expression of PPARA when injected with the PPAR ligand clofibrate (Litherland et al., 2010), this ligand increased or tended to increase expression of the PPARA target genes ACADVL, ACOX1, and CPT1A. Furthermore, work with bovine kidney cells recently showed that palmitate, stearate, and eicosapentanoate also could activate PPARA-regulated pathways (Bionaz et al., 2012). Therefore, the relative change in expression of PPAR target genes could be taken as indicators of treatment effects on the activity of this nuclear receptor.

The lack of increase in expression of PPARA among treatments at $7 \mathrm{~d}$ (Table 1 ) and between 7 and 14 DIM (Figure 7) in OVE-LPS compared with CON-LPS cows might be explained in part by a derangement in the mechanisms that needed to be in place for the PPARA response to take place; for example, downregulation of RXR or other co-activators (Pyper et al., 2010). Furthermore, GH signaling in liver might be mechanistically linked with PPARA, as is the case in rodents (Ljungberg et al., 2007). The fact that both STAT5B and SOCS2 decreased markedly between 7 and 14 DIM only in OVE-LPS cows suggested an exacerbated uncoupling of the GH/IGF-1 axis (Lucy, 2008).

Cows in the CON-LPS group clearly responded in a way that might have been expected under normal physiological conditions. The response in PPARA and $A C O X 1$, in particular, between 7 and 14 DIM in CONLPS cows followed the same trend (Figure 7) and appeared to be inversely associated (at least through d 14) with concentrations of liver TAG and blood NEFA 
and BHBA (Figure 4). Those data seemed to provide additional evidence for the importance of this pathway in handling the surge of LCFA early postpartum (Grum et al., 1996). Together, the coordinated response in PPARA and ACOX1 may have been associated with greater rates of LCFA oxidation, as shown in dairy calves dosed with clofibrate (Litherland et al., 2010). In dairy cows grouped retrospectively based on concentrations of BHBA, the correlations between BHBA and $H M G C S 2$ at $4 \mathrm{wk}$ in lactation were significant regardless of grouping (van Dorland et al., 2009). Interestingly, in that study, the group with greater BHBA concentration also had a positive correlation between HMGCS2 and CPT1A, as we observed in CON-LPS cows.

Taken together, these data seem to suggest that, despite increasing availability of NEFA to liver, energy overfeeding resulted in other alterations (e.g., inflammation) that dampened PPAR signaling. The lack of change in CPT1A between treatments (Table 1) is somewhat opposite to what was observed in mid lactation cows injected with TNF (Bradford et al., 2009), where CPT1A expression was reduced. Despite those differences, however, the NEFA, BHBA, and liver TAG data observed in the present study were suggestive of inflammation potentially inhibiting fatty acid oxidation in the short term (NEFA and BHBA data in Figure 1); as such, those effects would result in TAG accumulation partly through increases in expression of $C D 36$ and AGPAT mRNA expression (Khovidhunkit et al., 2004). The decrease in expression of DGAT1 coupled with the lower MTTP between 7 and 30 DIM regardless of diet may indicate a reduction in VLDL synthesis. The endoplasmic reticulum-bound DGAT1 enzyme, rather than the cytosolic DGAT2, is thought to be associated with channeling of LCFA toward the endoplasmic reticulum lumen for TAG synthesis and assembly of mature VLDL (Lavoie and Gauthier, 2006). The upregulation of DGAT1 (Table 1) after LPS challenge, coupled with the increase in blood NEFA and TAG (Figure 1), was suggestive of an acute adaptation in liver to handle excess LCFA. Together with the decrease in blood TAG between 7 and 14 DIM (Figure 2), particularly in CONLPS cows, these data seem to support a role of DGAT1 in VLDL synthesis.

The contrasting responses between groups in regards to BHBA, NEFA, ACOX1, PPARA, HMGCS2, (Table 1), and liver TAG (Figure 3) point at additional mechanisms in CON-LPS cows that prevented hepatic accumulation of TAG despite the apparent decrease in ketogenesis; that is, lower BHBA from 7 through 14 DIM. In that regard, it should be noted that an important effect of PPARA on systemic lipid metabolism is its positive effect on peripheral VLDL utilization, a process driven via upregulation of hepatic APOA5 and its positive effect on the activation of lipoprotein lipase in peripheral tissues (Kraja et al., 2010).

\section{Hepatic Expression of Inflammation- and Stress-Related Genes}

The striking upregulation of TNF, TLR4, NFKB1, and SOD2 at approximately $2.5 \mathrm{~h}$ post-LPS challenge (Table 1) reflected the acute response to inflammation. The same could be envisaged for ANGPTL4, which has recently been shown to respond as a positive acute phase protein in mice challenged with LPS ( $\mathrm{Lu}$ et al., 2010). Hepatic expression of the well-known proinflammatory cytokine $T N F$ was upregulated at $\sim 3 \mathrm{~h}$ postinfusion of LPS in mid-lactation dairy cows (Vels et al., 2009). Previous work with peripartal cows showed that activity of superoxide dismutase in erythrocytes was higher prepartum than postpartum, but blood indices of oxidative stress (e.g., ROM, thiobarbituric acid-reactive substances) were greater postpartum than prepartum; that is, oxidative stress is a characteristic of the peripartal period (Bernabucci et al., 2005).

The fact that expression of PPARD, and not $P P A$ $R A$, increased with LPS at $2.5 \mathrm{~h}$ post-LPS and followed the same pattern as expression of the proinflammatory genes and ANGPTL4 suggested a mechanistic link between this nuclear receptor and the control of inflammation, as has been shown in nonruminant skeletal muscle (Ding et al., 2006). This response also could be taken as indication that PPARD exerts partial control of $A N G$ PTL4 as shown in nonruminants (Staiger et al., 2009); for example, a PPARD-specific ligand (GW501516 vs. Wy-14,643) upregulated ANGPTL4 expression to the greatest extent in vitro (Staiger et al., 2009). Whether exogenous NEFA (not from lipolysis) played a role in the PPARD response observed remains to be elucidated; however, in vitro data from nonruminants demonstrated that saturated $(16: 0)$ and unsaturated (cis-9 18:1, 18:2 n-6) LCFA can increase mRNA and intracellular protein content of ANGPTL4. The fact that secreted ANGPTL4 is likely metabolized by peripheral tissues complicates a more thorough interpretation of its role in hepatic adaptations to inflammation.

The marked upregulation of TLR 4 in response to LPS (Table 1) and the relatively similar pattern of expression observed for NFKB1 and MYD88 (along with $T N F$ and IRAK1) after 7 DIM suggested the existence of TLR4-mediated signaling, likely due to direct binding of LPS; that is, this molecule seems to be a hepatic agonist of toll-like receptor (TLR)-4, as proposed in bovine macrophages (Ibeagha-Awemu et al., 2008). Moreover, IRAK1 is a key mediator of TLR/MYD88 signaling during bacterial infections, which leads to robust inflammatory target gene expression, in part 
via NFKB1 activation (Taraktsoglou et al., 2011). We previously found upregulation of IRAK1 in mammary tissue and blood neutrophils from dairy cows receiving an intramammary challenge with Streptococcus uberis (Moyes et al., 2010a,b). The marked upregulation of NFKB1 (Table 1) with LPS seems to confirm its role in the TLR pathway. In regard to immune response, the marked downregulation of SOCS2, which regulates STAT5B (Nicholson and Hilton, 1998), between 7 and 14 DIM in OVE-LPS cows suggested a compromised response to inflammation, because this protein negatively regulates cytokine signaling (Udy et al., 1997).

\section{CONCLUSIONS}

Overall, the responses observed in energy-overfed cows challenged with LPS were suggestive of alterations of metabolism and oxidative stress that spanned several days; for example, sustained elevations in circulating NEFA and ROM, and might affect negatively the immune system and render the animal more susceptible to pathogens. A potentially unique link between PPARD activation and inflammation in liver, similar to what has been observed in nonruminants, was uncovered. The long-term consequences of these multifaceted changes on fertility remain to be elucidated.

\section{ACKNOWLEDGMENTS}

The authors thank Travis Michels and Mike Katterhenry of the University of Illinois Dairy Research Unit (Urbana) staff for help with animal management, and Mario Ordonez and Manish Mukesh (National Bureau of Animal Genetic Resources, Karnal, India) for help during sampling and data collection. Appreciation also is extended to Walter Hurley, Janeen Salak-Johnson, Richard L. Wallace, and Dawn Morin (University of Illinois, Urbana) for helpful discussions during development and conduct of the project. The help of Massimo Bionaz (University of Illinois, Urbana) during portions of this study is greatly appreciated.

\section{REFERENCES}

Ametaj, B. N., B. J. Bradford, G. Bobe, R. A. Nafikov, Y. Lu, J. W. Young, and D. C. Beitz. 2005. Strong relationships between mediators of the acute phase response and fatty liver in dairy cows. Can. J. Anim. Sci. 85:165-175.

Assenat, E., S. Gerbal-Chaloin, D. Larrey, J. Saric, J. M. Fabre, P. Maurel, M. J. Vilarem, and J. M. Pascussi. 2004. Interleukin 1beta inhibits CAR-induced expression of hepatic genes involved in drug and bilirubin clearance. Hepatology 40:951-960.

Beever, D. E. 2006. The impact of controlled nutrition during the dry period on dairy cow health, fertility and performance. Anim. Reprod. Sci. 96:212-226.

Bernabucci, U., B. Ronchi, N. Lacetera, and A. Nardone. 2005. Influence of body condition score on relationships between metabolic status and oxidative stress in periparturient dairy cows. J. Dairy Sci. 88:2017-2026

Bertoni, G., E. Trevisi, M. Calamari, and M. Bionaz. 2006. The inflammation could have a role in the liver lipidosis occurrence in dairy cows. Pages 157-158 in Production Diseases in Farm Animals. N. Joshi and T. Herdt, ed. Wageningen Academic Publisher, Wageningen, the Netherlands.

Bertoni, G., E. Trevisi, X. Han, and M. Bionaz. 2008. Effects of inflammatory conditions on liver activity in puerperium period and consequences for performance in dairy cows. J. Dairy Sci. 91:3300-3310.

Bionaz, M., B. J. Thering, and J. J. Loor. 2012. Fine metabolic regulation in ruminants via nutrient-gene interactions: Saturated longchain fatty acids increase expression of genes involved in lipid metabolism and immune response partly through PPAR-alpha activation. Br. J. Nutr. 107:179-191.

Bionaz, M., E. Trevisi, L. Calamari, F. Librandi, A. Ferrari, and G Bertoni. 2007. Plasma paraoxonase, health, inflammatory conditions, and liver function in transition dairy cows. J. Dairy Sci. 90:1740-1750.

Bradford, B. J., L. K. Mamedova, J. E. Minton, J. S. Drouillard, and B. J. Johnson. 2009. Daily injection of tumor necrosis factor- $\alpha$ increases hepatic triglycerides and alters transcript abundance of metabolic genes in lactating dairy cattle. J. Nutr. 139:1451-1456.

Burvenich, C., V. Van Merris, J. Mehrzad, A. Diez-Fraile, and L. Duchateau. 2003. Severity of E. coli mastitis is mainly determined by cow factors. Vet. Res. 34:521-564.

Cavestany, D., J. E. Blanc, M. Kulcsar, G. Uriarte, P. Chilibroste, A. Meikle, H. Febel, A. Ferraris, and E. Krall. 2005. Studies of the transition cow under a pasture-based milk production system: Metabolic profiles. J. Vet. Med. A Physiol. Pathol. Clin. Med. $52: 1-7$

Dann, H. M., N. B. Litherland, J. P. Underwood, M. Bionaz, A. D'Angelo, J. W. McFadden, and J. K. Drackley. 2006. Diets during far-off and close-up dry periods affect periparturient metabolism and lactation in multiparous cows. J. Dairy Sci. 89:3563-3577.

Dann, H. M., D. E. Morin, G. A. Bollero, M. R. Murphy, and J. K. Drackley. 2005. Prepartum intake, postpartum induction of ketosis, and periparturient disorders affect the metabolic status of dairy cows. J. Dairy Sci. 88:3249-3264.

Ding, G., L. Cheng, Q. Qin, S. Frontin, and Q. Yang. 2006. PPAR modulates lipopolysaccharide-induced TNFQ inflammation signaling in cultured cardiomyocytes. J. Mol. Cell. Cardiol. 40:821-828.

Douglas, G. N., T. R. Overton, H. G. Bateman 2nd, H. M. Dann, and J. K. Drackley. 2006. Prepartal plane of nutrition, regardless of dietary energy source, affects periparturient metabolism and dry matter intake in Holstein cows. J. Dairy Sci. 89:2141-2157.

Drackley, J. K., H. M. Dann, G. N. Douglas, N. A. J. Guretzky, N. B. Litherland, J. P. Underwood, and J. J. Loor. 2005. Physiological and pathological adaptations in dairy cows that may increase susceptibility to periparturient diseases and disorders. Ital. J. Anim. Sci. 4:323-344

Goff, J. P. 2006. Major advances in our understanding of nutritional influences on bovine health. J. Dairy Sci. 89:1292-1301.

Graugnard, D. E., M. Bionaz, E. Trevisi, K. M. Moyes, J. L. SalakJohnson, R. L. Wallace, J. K. Drackley, G. Bertoni, and J. J. Loor. 2012. Blood immunometabolic indices and polymorphonuclear neutrophil function in peripartum dairy cows are altered by level of dietary energy prepartum. J. Dairy Sci. 95:1749-1758.

Grum, D. E., J. K. Drackley, R. S. Younker, D. W. LaCount, and J. J. Veenhuizen. 1996. Nutrition during the dry period and hepatic lipid metabolism of periparturient dairy cows. J. Dairy Sci. 79:1850-1864.

Hayirli, A., R. R. Grummer, E. V. Nordheim, and P. M. Crump. 2002. Animal and dietary factors affecting feed intake during the prefresh transition period in Holsteins. J. Dairy Sci. 85:3430-3443.

Hoeben, D., C. Burvenich, E. Trevisi, G. Bertoni, J. Hamann, R. M Bruckmaier, and J. W. Blum. 2000. Role of endotoxin and TNFalpha in the pathogenesis of experimentally induced coliform mastitis in periparturient cows. J. Dairy Res. 67:503-514. 
Ibeagha-Awemu, E. M., J. W. Lee, A. E. Ibeagha, D. D. Bannerman, M. J. Paape, and X. Zhao. 2008. Bacterial lipopolysaccharide induces increased expression of toll-like receptor (TLR) 4 and downstream TLR signaling molecules in bovine mammary epithelial cells. Vet. Res. 39:11.

Janovick, N. A., Y. R. Boisclair, and J. K. Drackley. 2011. Prepartum dietary energy intake affects metabolism and health during the periparturient period in primiparous and multiparous Holstein cows. J. Dairy Sci. 94:1385-1400.

Janovick, N. A., and J. K. Drackley. 2010. Prepartum dietary management of energy intake affects postpartum intake and lactation performance by primiparous and multiparous Holstein cows. J. Dairy Sci. 93:3086-3102.

Kersten, S., J. Seydoux, J. M. Peters, F. J. Gonzalez, B. Desvergne, and W. Wahli. 1999. Peroxisome proliferator-activated receptor alpha mediates the adaptive response to fasting. J. Clin. Invest. 103:1489-1498.

Khovidhunkit, W., M. S. Kim, R. A. Memon, J. K. Shigenaga, A. H. Moser, K. R. Feingold, and C. Grunfeld. 2004. Effects of infection and inflammation on lipid and lipoprotein metabolism: Mechanisms and consequences to the host. J. Lipid Res. 45:1169-1196.

Kraja, A. T., M. A. Province, R. J. Straka, J. M. Ordovas, I. B. Borecki, and D. K. Arnett. 2010. Fenofibrate and metabolic syndrome. Endocr. Metab. Immune Disord. Drug Targets 10:138148.

Kushibiki, S., K. Hodate, H. Shingu, Y. Obara, E. Touno, M. Shinoda, and Y. Yokomizo. 2003. Metabolic and lactational responses during recombinant bovine tumor necrosis factor-alpha treatment in lactating cows. J. Dairy Sci. 86:819-827.

Lavoie, J. M., and M. S. Gauthier. 2006. Regulation of fat metabolism in the liver: Link to non-alcoholic hepatic steatosis and impact of physical exercise. Cell. Mol. Life Sci. 63:1393-1409.

Litherland, N. B., M. Bionaz, R. L. Wallace, J. J. Loor, and J. K. Drackley. 2010. Effects of the peroxisome proliferator-activated receptor-alpha agonists clofibrate and fish oil on hepatic fatty acid metabolism in weaned dairy calves. J. Dairy Sci. 93:2404-2418.

Ljungberg, A., D. Linden, C. Ameen, G. Bergstrom, and J. Oscarsson. 2007. Importance of PPAR alpha for the effects of growth hormone on hepatic lipid and lipoprotein metabolism. Growth Horm. IGF Res. 17:154-164.

Loor, J. J., H. M. Dann, R. E. Everts, R. Oliveira, C. A. Green, N. A. Guretzky, S. L. Rodriguez-Zas, H. A. Lewin, and J. K. Drackley. 2005. Temporal gene expression profiling of liver from periparturient dairy cows reveals complex adaptive mechanisms in hepatic function. Physiol. Genomics 23:217-226.

Lu, B., A. Moser, J. K. Shigenaga, C. Grunfeld, and K. R. Feingold. 2010. The acute phase response stimulates the expression of angiopoietin like protein 4. Biochem. Biophys. Res. Commun. 391:1737-1741.

Lucy, M. C. 2008. Functional differences in the growth hormone and insulin-like growth factor axis in cattle and pigs: Implications for post-partum nutrition and reproduction. Reprod. Domest. Anim. 43(Suppl. 2):31-39.

Moyes, K. M., J. K. Drackley, D. E. Morin, and J. J. Loor. 2010a. Greater expression of TLR2, TLR4, and IL6 due to negative energy balance is associated with lower expression of HLA-DRA and HLA-A in bovine blood neutrophils after intramammary mastitis challenge with Streptococcus uberis. Funct. Integr. Genomics 10:53-61.

Moyes, K. M., J. K. Drackley, D. E. Morin, S. L. Rodriguez-Zas, R. E. Everts, H. A. Lewin, and J. J. Loor. 2010b. Mammary gene expression profiles during an intramammary challenge reveal potential mechanisms linking negative energy balance with impaired immune response. Physiol. Genomics . 41:161-170.

Moyes, K. M., J. K. Drackley, J. L. Salak-Johnson, D. E. Morin, J. C. Hope, and J. J. Loor. 2009. Dietary-induced negative energy balance has minimal effects on innate immunity during a Streptococcus uberis mastitis challenge in dairy cows during midlactation. J. Dairy Sci. 92:4301-4316.
Nicholson, S. E., and D. J. Hilton. 1998. The SOCS proteins: A new family of negative regulators of signal transduction. J. Leukoc. Biol. 63:665-668.

Nikkhah, A., J. J. Loor, R. J. Wallace, D. E. Graugnard, J. Vasquez, B. Richards, and J. K. Drackley. 2008. Moderate excesses of dietary energy markedly increase visceral adipose tissue mass in nonlactating dairy cows. J. Dairy Sci. 91(E-Suppl. 1):ii. (Abstr.)

NRC. 2001. Nutrient Requirements of Dairy Cattle. 7th rev. ed. Natl. Acad. Sci., Washington, DC.

Pedernera, M., P. Celi, S. C. Garcia, H. E. Salvin, I. Barchia, and W. J. Fulkerson. 2010. Effect of diet, energy balance and milk production on oxidative stress in early-lactating dairy cows grazing pasture. Vet. J. 186:352-357.

Pyper, S. R., N. Viswakarma, S. Yu, and J. K. Reddy. 2010. PPARo: Energy combustion, hypolipidemia, inflammation and cancer. Nucl. Recept. Signal. 8:e002.

Rukkwamsuk, T., T. A. Kruip, and T. Wensing. 1999. Relationship between overfeeding and overconditioning in the dry period and the problems of high producing dairy cows during the postparturient period. Vet. Q. 21:71-77.

Selberg, K. T., C. R. Staples, N. D. Luchini, and L. Badinga. 2005. Dietary trans octadecenoic acids upregulate the liver gene encoding peroxisome proliferator-activated receptor- $\alpha$ in transition dairy cows. J. Dairy Res. 72:107-114.

Sordillo, L. M., and S. L. Aitken. 2009. Impact of oxidative stress on the health and immune function of dairy cattle. Vet. Immunol. Immunopathol. 128:104-109.

Sordillo, L. M., G. A. Contreras, and S. L. Aitken. 2009. Metabolic factors affecting the inflammatory response of periparturient dairy cows. Anim. Health Res. Rev. 10:53-63.

Staiger, H., C. Haas, J. Machann, R. Werner, M. Weisser, F. Schick, F. Machicao, N. Stefan, A. Fritsche, and H. U. Haring. 2009. Musclederived angiopoietin-like protein 4 is induced by fatty acids via peroxisome proliferator-activated receptor (PPAR)-delta and is of metabolic relevance in humans. Diabetes 58:579-589.

Taraktsoglou, M., U. Szalabska, D. A. Magee, J. A. Browne, T. Sweeney, E. Gormley, and D. E. MacHugh. 2011. Transcriptional profiling of immune genes in bovine monocyte-derived macrophages exposed to bacterial antigens. Vet. Immunol. Immunopathol. 140:130-139.

Trevisi, E., M. Amadori, A. M. Bakudila, and G. Bertoni. 2009. Metabolic changes in dairy cows induced by oral, low-dose interferonalpha treatment. J. Anim. Sci. 87:3020-3029.

Trevisi, E., A. Zecconi, G. Bertoni, and R. Piccinini. 2010. Blood and milk immune and inflammatory profiles in periparturient dairy cows showing a different liver activity index. J. Dairy Res. $77: 310-317$.

Udy, G. B., R. P. Towers, R. G. Snell, R. J. Wilkins, S. H. Park, P. A. Ram, D. J. Waxman, and H. W. Davey. 1997. Requirement of STAT5b for sexual dimorphism of body growth rates and liver gene expression. Proc. Natl. Acad. Sci. USA 94:7239-7244.

van Dorland, H. A., S. Richter, I. Morel, M. G. Doherr, N. Castro, and R. M. Bruckmaier. 2009. Variation in hepatic regulation of metabolism during the dry period and in early lactation in dairy cows. J. Dairy Sci. 92:1924-1940.

Vels, L., C. M. Rontved, M. Bjerring, and K. L. Ingvartsen. 2009. Cytokine and acute phase protein gene expression in repeated liver biopsies of dairy cows with a lipopolysaccharide-induced mastitis. J. Dairy Sci. 92:922-934.

Vernay, M. C., O. Wellnitz, L. Kreipe, H. A. van Dorland, and R. M. Bruckmaier. 2012. Local and systemic response to intramammary lipopolysaccharide challenge during long-term manipulated plasma glucose and insulin concentrations in dairy cows. J. Dairy Sci. 95:2540-2549.

Waldron, M. R., T. Nishida, B. J. Nonnecke, and T. R. Overton. 2003. Effect of lipopolysaccharide on indices of peripheral and hepatic metabolism in lactating cows. J. Dairy Sci. 86:3447-3459.

Zu, L., J. He, H. Jiang, C. Xu, S. Pu, and G. Xu. 2009. Bacterial endotoxin stimulates adipose lipolysis via toll-like receptor 4 and extracellular signal-regulated kinase pathway. J. Biol. Chem. 284:5915-5926. 